\title{
POLLUTION TRENDS USING BARK OF MORUS ALBA IN THE CITIES OF BUENOS AIRES AND MENDOZA (ARGENTINA) ${ }^{1}$
}

\author{
Patricia Perelman², Ana Faggi ${ }^{3}$, Maria Castro ${ }^{4}$ e Eduardo Martinez Carretero ${ }^{5}$
}

\begin{abstract}
A comparative study of elements deposited on tree bark was carried out for urban and periurban areas of two of the most important cities in Argentina. The content of $\mathrm{Fe}, \mathrm{Mg}, \mathrm{Al}, \mathrm{Mn}, \mathrm{Zn}, \mathrm{Pb}, \mathrm{Ba}, \mathrm{Cr}, \mathrm{Hg}$, $\mathrm{Cu}, \mathrm{Ni}, \mathrm{Cd}$ and $\mathrm{Sb}$ was determined by inductively coupled plasma atomic emission spectrometry (ICP-OES) in Morus alba tree bark collected in the cities of Buenos Aires and Mendoza. The main air pollutants detected in the Buenos Aires urban area were $\mathrm{Ba}, \mathrm{Cr}, \mathrm{Cu}$ and $\mathrm{Ni}$ and indicate significative difference from the Mendoza urban and periurban areas. Significantly, higher concentrations of $\mathrm{Zn}, \mathrm{Ba}, \mathrm{Cr}$ and $\mathrm{Cu}$ were recorded in the periurban area of the city of Buenos Aires than in Mendoza. Bark samples were strongly influenced by dust and show $\mathrm{Al}, \mathrm{Fe}, \mathrm{Mg}$ and other element accumulations that indicate that soil particles were carried out by wind. Elements like Ba and $\mathrm{Zn}$, commonly linked to traffic emissions, showed the highest concentrations in the Buenos Aires metropolitan area, possibly due to more intensive vehicular traffic. Our results indicated that intensity of vehicular traffic and not city structure is responsible for air pollution.
\end{abstract}

Keywords: Bark, Pollution and Morus Alba.

\section{TENDENCIAS DE POLUIÇÃO USANDO CASCAS DE MORUS ALBA NAS CIDADES DE BUENOS AIRES E MENDOZA (ARGENTINA)}

\begin{abstract}
RESUMO - Um estudo comparativo dos elementos depositados nas cascas das árvores foi realizado nas áreas urbanas e na periferia de duas cidades das mais importantes da Argentina. Os índices do Fe, Mg, Al, Mn, $\mathrm{Zn}, \mathrm{Pb}, \mathrm{Ba}, \mathrm{Cr}, \mathrm{Cu}$, Ni e do Sb foram determinados pela espectrometria da emissão atômica com plasma acoplado indutivamente (ICP-OES) nas cascas da árvore Morus alba, coletados nas cidades de Buenos Aires e Mendoza. Os principais elementos da contaminação do ar detectadas na área urbana de Buenos Aires foram $\mathrm{Ba}, \mathrm{Cr}$, Cu e Ni, que indicaram diferenças significativas nas áreas urbanas e na periferia de Mendoza. Uma concentração do $\mathrm{Zn}, \mathrm{Ba}$, Cr e do Cu foi achada na periferia da cidade de Buenos Aires, significativamente mais elevada do que em Mendoza. As amostras da casca foram influenciadas fortemente pela poeira e mostraram que $\mathrm{Al}, \mathrm{Fe}, \mathrm{Mg}$ e a acumulação de outros elementos indicaram que as partículas do solo foram espalhadas pelo vento. Na área metropolitana de Buenos Aires, o Ba e o Zn apresentaram as mais altas concentrações, possivelmente por causa do intenso tráfego automotor. O trabalho atual é uma contribuição preliminar, usando-se as árvores de Morus alba como um método indireto para estimar as tendências da poluição.
\end{abstract}

Palavras chave: Casca, Poluição e Morus Alba.

\section{INTRODUCTION}

The value of urban green is globally well recognized, considering that trees in the city fulfill multiple necessities from the environmental point of view (DA COSTA PORFIRIO et al. 2006). Urban trees can provide many benefits to the urban environment and society. These include numerous physical/biological and social/ economic benefits such as improved microclimates and air quality, enhanced physical and mental health, and increased economic development (NOVACK et al, 1997).

Air particulate matter is a combination of particles formed as a result of natural processes (pollen, soil erosion) or through human activities including different

\footnotetext{
${ }^{1}$ Recebido em 13.11.2007 e aceito para publicação em 02.03.2010.

${ }^{2}$ Museo Argentino de Ciencias Naturales, Buenos Aires, Argentina. E-mail: <patriperelman@yahoo.com.ar>.

${ }^{3}$ Museo Argentino de Ciencias Naturales, Buenos Aires, Argentina. E-mail: <afaggi@macn.gov.ar>.

${ }^{4}$ Facultad de Ciencias Exactas y Naturales -UBA. E-mail: <mac@bg.fcen.uba.ar>.

${ }^{5}$ CRICYT-CONICET. E-mail: <mcarrete@lab.cricyt.edu.ar>.
} 
industries, biomass burning, motor vehicle exhaust, mechanical wear, fungicide application, construction, mining, etc.(YAGHI and ABDUL-WAHAB, 2003)

Monitoring of air pollution is of great concern, especially in cities, because high concentrations of contaminants in closer proximity to humans can significantly amplify the exposure of man to metals with detrimental effects to health (DION et al, 1993; WONG et al, 2006).

The level of atmospheric pollution can be assessed by direct methods, e.g. measuring particles in the air, or indirect ones like biomonitoring. Monitoring using plants analyzes particles deposited or accumulated on mosses, lichens, epiphytes or in vascular plants. In many biomonitoring studies, authors used bark as a tracer of contamination in the environment, assuming that contents of pollutants in bark can be linked to levels of air pollution (BALLACH et al, 2002; WALKENHORST et al, 1993). Panichev and Mc Crindle (2004) found that metals assessed in bark reflected the levels of air pollution better than the leaves of trees or grasses did.

Tree bark is an ideal natural adsorbent: This dead tissue, which is exposed to the air for years, can give precise information about changes that occur in the air conditions (SPANGENBERG et al, 2002; BELLIS et al, 2003). Monitoring using bark represents an interesting and economic alternative to other methods, particularly when large areas have to be covered and air monitoring is not frequent. Bark pockets in trunks were reported by Bellis et al. (2003) to be historical monitors of arsenic concentration between 1846 and 2002. Rusu et al, (2006), concluded from the comparison of lichen and bark samples, that bark can be considered a "legacy of deposition”.

In recent years, the multielemental analysis of bark for discriminating sources of air contamination has been facilitated by the development of powerful analytical techniques, like inductively coupled plasma mass spectrometry - ICP-MS (BELLIS et al, 2003).

In Argentina, the data of air quality is scarce and direct methods for assessing pollutants are not frequently employed because of their high costs (GRACIANO et al, 2003). Indirect methods using lichens, bryophytes and bromeliaceous as biomonitors have been used to circumvent that limitation (GRACIANO et al, 2003; JASAN et al, 2004; PIGNATA et al, 2002; CARRERAS et al,
2005). On the contrary, bark has been less used for biomonitoring purposes. Pla et al. (2000) used Neutron Activation Analysis on Platanus acerifolia bark to compare pollution levels in urban and rural locations. In the city of Buenos Aires, Perelman et al., (2006) used green ash (Fraxinus pennsylvanica) tree bark and inductively coupled plasma atomic emission spectrometry - ICP-OES- techniques to find $\mathrm{Ba}, \mathrm{Cu}, \mathrm{Fe}, \mathrm{Al}, \mathrm{Ni}, \mathrm{Pb}$ and $\mathrm{Cr}$ from geogenic and anthropogenic sources emission.

In the present work, we analyzed the concentration of metals in the bark of Morus alba (white mulberry) with an ICP-OES analytical technique. Our objective is to compare trends of pollution between a metropole and a mid-city along an urban gradient. As far as we are aware of, this is the first study in which Morus alba bark samples are used to compare particulate deposition in two of the most important urban conglomerates in Argentina. Similar to our work, Alves et al (2004) analyzed environmental impacts observed in Teixeira, PB along a gradient urban area.

Air quality information from both cities is both fragmentary and scarce. Puliafito et al.(1995) found an average of $80-\mu \mathrm{g} \mathrm{m}^{-3}$ for total particulates in the city of Mendoza, mostly from road-traffic emissions. Fujiwara et al, (2006) reported lower values for particulate matter in the city of Buenos Aires (PM10 $=37 \mathrm{ug} / \mathrm{m}^{3}$ and PM 2.5 $=22 \mathrm{ug} / \mathrm{m}^{3}$ ). Thermal power plants that burn mostly natural gas and liquid fossil fuels only in wintertime and peripheral petrochemical industries close to both cities possibly raise the concentration of particles.

We hypothesize that: a) tree barks from areas with intensive vehicular traffic will contain higher values of metals; b) bark reflects a multielemental profile, which own distinctive characteristics that allow a differentiation in sampling locations within and between cities.

\section{MATERIALAND METHODS}

\subsection{Study area}

The metropolitan area of Buenos Aires with about 14 million inhabitants comprises 25 districts with about $3830 \mathrm{~km}^{2}$. Mean annual temperature ranges from $13.1^{\circ} \mathrm{C}$ in town near the river (Jorge Newbery Airport, $34^{\circ} 34^{\prime}$ $\mathrm{S} ; 58^{\circ} 25^{\prime} \mathrm{W}$ ) to $14.2^{\circ} \mathrm{C}$ in the periurban sector (Ezeiza Airport, $34^{\circ} 49^{\prime} \mathrm{S}$; 58 $32^{\circ} \mathrm{W}$ ). Mean annual rainfall is above $1000 \mathrm{~mm}$, evenly distributed. The City of 
Mendoza is a medium-sized city of about $16.4 \mathrm{~km}^{2}$ and 800.000 inhabitants. It is located at the leeward side of the Andean ridge. Mean annual temperatures range from $16.3^{\circ} \mathrm{C}$ in the urban core (32 $53^{\prime} \mathrm{S}-68^{\circ} 52^{\prime} \mathrm{W}$ ) to $16^{\circ} \mathrm{C}$ in the periurban sector (Mendoza Airport, $\left.32^{\circ} 51^{\prime} \mathrm{S}-68^{\circ} 47 \mathrm{~W}\right)$. Mean annual rainfall varies between 204-and148 mm and occurs mainly during the summer (November-March).

Regional winds blowing from the river in Buenos Aires and from neighboring valleys and mountains in Mendoza have influence on the concentration and distribution of air pollutants in both cities.

\subsubsection{Bark sampling and analysis.}

Eighty bark samples of Morus alba (white mulberry) were collected in the fall of 2006 in the cities of Buenos Aires and Mendoza. We chose this tree because it is the preferred and dominant species used for shade in Mendoza and is also commonly found in Buenos Aires. Mature trees were selected along main streets in urban and periurban sectors. Both sectors were chosen because they represent different conditions of land use and traffic patterns.

In each tree one square sample $(10 \mathrm{~cm} \times 10 \mathrm{~cm})$ $3 \mathrm{~mm}$ thick was cut with a steel knife at $1.30 \mathrm{~m}$ height from the trunk facing the traffic and likely to be maximally exposed to air pollutants. Bark with lichen or moss growth was avoided. The characteristics of studied areas are the following:

\section{Buenos Aires:}

Urban: Located near the geographical center of the city close to a large park with a diameter of 500 m surrounded by a two-way street. The area is placed on a residential and commercial neighborhood. It is densely populated (258.3 people/ha) and exposed to emissions from heavy traffic (1628 vehicle/h) composed by cars and buses. The park vicinity offers ventilated conditions and favors dust re-suspension. Bark was collected from trees that are planted along the sidewalk that surrounds the park.

Periurban: Located on afforested areas used for recreation and scattered urbanization (5 people/ha), $35 \mathrm{~km}$ away from the centre and exposed to emissions from heavy traffic (1800 vehicle/h). Trees grew 50 to $100 \mathrm{~m}$ away from the highway. The International Airport is $5 \mathrm{~km}$ away.

\section{Mendoza:}

Urban: Residential and commercial area with low population (25 people/ha) and less traffic, mainly cars and buses (343 vehicles /h).

Periruban: Patches of settlements and cultivation fields located $18 \mathrm{~km}$ from downtown. Low population density (5 people/ha). Trees on lines at secondary roads and streets exposed to emissions from cars and trucks (242 vehicles/h).

\subsection{Chemical analysis}

We used inductively coupled plasma atomic emission spectrometry (ICP-OES) to identify chemical elements deposited on tree bark and incorporated in the tissues.

In each city individual bark samples were collected from 40 trees and air-dried. A $2 \mathrm{~g}$ sample of each of them was digested in $20 \mathrm{ml}$ of concentrated $\mathrm{NO}_{3} \mathrm{H}$ at $200^{\circ} \mathrm{C}$ during 12-24 hours. The resulting solution was filtered and bulked out to $100 \mathrm{ml}$ with deionizer water. Thirteen elements namely, Al, Ba, Cd, Cr, Cu, Fe, Mg, Mn, Ni, $\mathrm{Pb}, \mathrm{Sb}, \mathrm{Zn}$ and $\mathrm{Hg}$ were measured in three samples of this solution using a Perkin Elmer Optima 2000 DV.

\subsection{Statistical Analysis}

Mean concentrations were treated using ANOVA, test de Tuckey $(\mathrm{p}<0.05 \%)$.

\section{RESULTS}

Mean, maxima and minima concentrations values for the elements detected in bark are shown in Table 1. In all samples magnesium, aluminium and iron exhibited the largest concentrations. Lowest concentrations showed $\mathrm{Sb}, \mathrm{Cr}$ and $\mathrm{Cu}$, while $\mathrm{Hg}$ was found only in Mendoza.

Within both cities and contrary to our expectations, we did not find statistically significant differences in metals between urban and periurban areas. Our findings showed that in each city, both areas, although very different in structure, show similar trends of pollution. Hg was an exception. It was only detected in Mendoza; where the content of $\mathrm{Hg}$ in the periurban area $(7.5 \mathrm{mg} / \mathrm{kg})$ differed significantly from the trees collected in the centre.

Revista Árvore, Viçosa-MG, v.34, n.3, p.505-511, 2010 
Table 1 - Mean, maximum and minimum concentration values of elements.

Tabela 1 - Valores méios, máximos e mínimos da concentração dos elementos.

\begin{tabular}{ccccc}
\hline & Mendozaurban & Mendozaperiurban & Buenos Airesurban & Buenos Airesperiurban \\
\hline $\mathrm{Mg}$ & $1127.5(1040-1190)$ & $1470(1300-1800)$ & $1129(789-1280)$ & $1908(1070-3630)$ \\
$\mathrm{Al}$ & $389(297-563)$ & $455.5(184-590)$ & $510.25(159-1010)$ & $949.2(248-2100)$ \\
$\mathrm{Fe}$ & $393.7(245-723)$ & $589.5(265-881)$ & $399(181-623)$ & $497(243-1170)$ \\
$\mathrm{Mn}$ & $21.35(13.5-31.4)$ & $22.47(17.2-29.2)$ & $16.28(9.6-24.3)$ & $30.76(13.1-63)$ \\
$\mathrm{Zn}$ & $22.9(11-38.8)^{\mathrm{ab}}$ & $8.46(7.2-11.2)^{\mathrm{b}}$ & $19.55(9.4-35.4)^{\mathrm{ab}}$ & $29.46(19.2-54.7)^{\mathrm{a}}$ \\
$\mathrm{Pb}$ & $29.9(2.3-79)$ & $1.85(0.2-3)$ & $4.59(1.9-8.7)$ & $8.67(3.3-25.3)$ \\
$\mathrm{Ba}$ & $13.4(8-20.6)^{\mathrm{a}}$ & $11.75(8.1-14.7)^{\mathrm{a}}$ & $72.97(41.1-86.6)^{\mathrm{b}}$ & $51.14(43.8-60)^{\mathrm{b}}$ \\
$\mathrm{Cr}$ & $2.69(0.1-5.2)^{\mathrm{a}}$ & $0.172(0.1-0.39)^{\mathrm{a}}$ & $51.4(41.6-57.9)^{\mathrm{b}}$ & $43.9(20.1-94)^{\mathrm{b}}$ \\
$\mathrm{Cu}$ & $0.825(0.2-2.7)^{\mathrm{a}}$ & $0.2(0.2-0.2)^{\mathrm{a}}$ & $13.45(6.3-26.4)^{\mathrm{b}}$ & $38.4(4.4-123)^{\mathrm{b}}$ \\
$\mathrm{Ni}$ & $0.98(0.86-1.31)^{\mathrm{a}}$ & $1.19(0.85-1.7)^{\mathrm{a}}$ & $3(1.91-3.74)^{\mathrm{b}}$ & $2.53(0.6-3.9)^{\mathrm{ab}}$ \\
$\mathrm{Sb}$ & $0,35(0.2-0.83)^{\mathrm{b}}$ & $0,62(0.2-1.28)$ & $0.11(0.09-0.132)$ & $0.17(0.02-0.37)$ \\
$\mathrm{Hg}$ & $3.85(2.5-5.9)^{\mathrm{a}}$ & $7.5(4.9-9.8)^{\mathrm{b}}$ & - & - \\
\hline
\end{tabular}

Diferent letters indicate significative differences at the level $\mathrm{P}<0.05$.

Statistically significant differences in the concentration of some elements were found between Buenos Aires and Mendoza in both urban and periurban areas. Buenos Aires vs. Mendoza showed higher levels of $\mathrm{Ba}, \mathrm{Cu}, \mathrm{Ni}$, and $\mathrm{Cr}$ comparing the urban areas and of $\mathrm{Ba}, \mathrm{Zn}, \mathrm{Cu}$ and $\mathrm{Cr}$ between the periurban ones. $\mathrm{Cu}$ concentrations in Buenos Aires were almost 17 fold the Mendoza values in the urban sector and 192 fold higher in the periurban area.

\section{DISCUSSION}

As expected the higher observed values of $\mathrm{Mg}$, $\mathrm{Al}$ and Fe, elements that are mainly associated with the topsoil, indicated its crustal nature. This result was coincident with the findings of Wannaz et al. 2006, which tested Tillandsia capillaris as a metal accumulator in passive biomonitoring studies in central Argentina. Nevertheless, those elements might also be associated with anthropogenic activities. Some authors related also the presence of Al to coal combustion (GOMEZ et al, 2007) and wear and tear of construction materials. Fe was also associated to highway infrastructure facilities, industrial activities, corrosion of materials, vehicular traffic and the use of additives (FUJIWARA et al, 2006; FIGUEIREDO et al, 2007).

We could not confirm our hypothesis of differentiation within cities. In Buenos Aires our results showed similar metal concentrations in bark in the urban and periurban areas. Our results were not consistent with the "potential contamination index" estimated by Zellner et al., 1996. These authors constructed an index taking into account the mean vehicular speed and the urban structure (height of buildings, ventilation and street width). Following this index, the urban areas in Buenos Aires should be 6.5 times more contaminated than the periurban ones, a situation which is disregarded using bark. These results indicated that the use of potential indicators based on urban structural features should be treated with caution.

In Buenos Aires the periurban area dominated by a treed canopy, meadows and recreational facilities, was very much influenced by the vehicular trafficusually very intense-from the highway connecting the city with the nearby international airport. In the periurban area the number of vehicles was higher than in the city and the air traffic might have also had an influence on the emissions. On the contrary, in Mendoza, vehicular traffic was higher than in the periurban.

The results allowed the confirmation of our hypothesis of differentiation between a metropolis and a mid-city. Statistically significant differences in the concentration of some elements between Buenos Aires and Mendoza in both urban and periurban areas could be related to a difference in traffic intensity. The number of vehicles in use in the downtown area of Buenos Aires was almost 5-fold the values observed in Mendoza.

Significantly higher concentrations of all the elements detected in bark collected in Buenos Aires could be associated with the particulate emissions produced by fuel combustion, wear and tear of vehicular parts and leakage of motor oils (PLA et al, 1997; ZELLNER et al, 1996), from a large metropolis with about 1.5 million cars in daily traffic. 
$\mathrm{Pb}$ was clearly enriched in the downtown area of Buenos Aires and could be associated with anthropogenic sources. Although in Argentina $\mathrm{Pb}$ was no longer added to gasoline since 1995, it is nevertheless present at trace levels as a natural component in fuels. Vehicular $\mathrm{Pb}$ emissions are now caused mainly from brake wear and loss of $\mathrm{Pb}$ wheel weights.

Nevertheless Pb bark contents sampled in Buenos Aires and Mendoza are much below the elevated values (150 and 225 ppm) found in Fraxinus excelsior in Frankfurt, Germany (BALLACH et al, 2002).

The concentrations of $\mathrm{Hg}$ in Mendoza, suggested a possible influence of domestic and pathologic waste burning but also by fires in agriculture, which are very common in the piedmont. Higher values in the periurban could also be related to mining activities for the extraction of $\mathrm{Au}, \mathrm{Cu}$ and precious metals.

Significantly, higher concentrations of Ba were recorded in the urban and periurban areas of Buenos Aires than in Mendoza. They could be attributed to the exhaust of diesel engines from buses and trucks, because barium is used as a fuel additive to reduce combustion smoke (FIGUEIREDO et al, 2007). Ba could also be linked to gas oil incineration for heating.

The significant higher presence of Copper in Buenos Aires might also be related to anthropogenic activities. In a previous work Perelman et al., 2006 found higher $\mathrm{Cu}$ contents than those collected in the downtown area in barks of green ash (Fraxinus pennsylvanica), sampled in the Buenos Aires periurban area. They pointed to emissions coming from water purification of swimming pools that are abundant in the periurban area (BALLACH et al, 2002) and the use of pesticides.

The urban areas of Buenos Aires differed significantly from the Mendoza urban and periurban areas in $\mathrm{Ni}$ concentrations. Nickel is an element related to industrial activities and waste (BIRKE and RAUCH, 2000). The $\mathrm{Cu}$ and $\mathrm{Ni}$ levels found in Mendoza were similar to the results reported by Pignata et al. 2002. These authors used epithytic Bromeliaceae (Tillandsia capillaris) as the biomonitor in Cordoba, located in the central region of Argentina, which is comparable to the economic and infrastructure development of Mendoza.

A significantly higher concentration of $\mathrm{Cr}$ in Buenos Aires could be associated with leather manufacturing, diverse industrial processes, waste incineration, coal and fuel combustion.
The periurban areas differed significantly in $\mathrm{Zn}$ concentration, which in Buenos Aires was threefold the Mendoza value, very likely because the deposition of $\mathrm{Zn}$ is strongly related to emissions from vehicle combustion for the use of lubricant oils (FIGUEIREDO et al, 2007; FUJIWARA et al, 2006), and to the use of fungicides (PIGNATA et al, 2002). Similar mean values of $\mathrm{Zn}(31.87 \mu \mathrm{g} / \mathrm{g})$ were reported by Carreras et al. 2005, transplanting Usnea amblyoclada from a natural to polluted area in Córdoba City (central Argentina).

\section{CONCLUSIONS}

Similar concentrations of metals by comparing urban and periurban areas within cities indicated that traffic and non city structures evoked pollution homogenization between these categories. However, some differences were found in Mendoza for $\mathrm{Hg}$.

Significant differences were found between the Buenos Aires and Mendoza urban/periurban areas in $\mathrm{Ba}, \mathrm{Cr}$ and Cu contents; Buenos Aires periurban areas and Mendoza periurban areas in $\mathrm{Zn}$ content and Buenos Aires urban areas and Mendoza urban/periurban areas in Ni.

Elements like Ba and Zn, commonly linked to traffic emissions, showed the highest concentrations in the Buenos Aires metropolitan area possibly by more intense vehicular traffic. The higher concentration of $\mathrm{Cu}, \mathrm{Cr}$ and $\mathrm{Ni}$ in Buenos Aires were possibly also due to the higher industrial activities.

\section{ACKNOWLEDGEMENT}

This study was supported by SECYT under the project PICT 14039.

\section{REFERENCES}

ALVES, J. B. et al. Diagnóstico ambiental de ruas e bairros da cidade de Teixeira, PB.Revista Árvore, v.28, n.5, p.755-764, 2000.

BALLACH, H. J.; WITTIG, R.; WULFF, S. TwentyFive years of biomonitoring lead in the Frankfurt/ Main area. Environmental Science and Pollution Research International, v.9, n.2, p.136-42, 2002.

BELLIS, D. et al. Environmental monitoring of historical change in arsenic deposition with tree bark pockets. Journal of Environmental Monitoring, v 5, n 4, p.671-674, 2003. 
BIRKE, M.; RAUCH, U. Urban geochemistry: investigation in the Berlin Metropolitan area. Environmental Geochemistry and Health, v.22, n.3, p. 233-248, 2000.

CARRERAS, H. E. et al. The role of urban air pollutants on the performance of heavy metal accumulation in Usnea amblyoclada Environmental Research, v.97n.1, p.50-57 2005

DA COSTA PORFIRIO, T. H. et al. Formas de interação de três bairros periféricos como o Parque Municipal Das Mangabeiras, Belo Horizonte, Minas Gerais. Revista Árvore, v.30, n.6, p.1033-1038, 2006.

DION, M. et al. Evaluation of black spruce (Picea mariana) as a bioindicator of aluminium contamination.Water, Air and Soil Pollution, v. 71, n.1, p.29-41,1993.

FIGUEIREDO, A. M. G. et al. Assessment of atmospheric metallic pollution in the metropolitan region of Sao Paulo, Brazil, employing Tillandsia usneoides L. as biomonitor. Environmental Pollution, v.145, n.1, p.279-292, 2007.

FUJIWARA, F. et al. Fractionation of eleven elements by chemical bonding from airborne particulate matter collected in an industrial city in Argentina. Journal of Environmental Monitoring, v.8, n.9, p.913-922, 2006.

GÓMEZ, D. et al. A combined analysis to identify airborne $\mathrm{PM}_{10}$ sources. Journal of Environmental Monitoring, v.7, n.1, p.52-59, 2005.

GÓMEZ, D. et al. Fractionation of metals and metalloids by chemical bonding from particles accumulated by electrostatic precipitation in an Argentine thermal power plant. Microchemical Journal, v.85, n.2, p.276-284, 2007.

GRACIANO, C.; FERNÁNDEZ, L. V.; CALDIZ, D. O. Tillandsia recurvata $\mathrm{L}$ as a bioindicator of sulfur atmospheric pollution. Ecología Austral, v.13, n.1, p.3-14, 2003.
JASAN, R. C. et al. On the use of the lichen Ramalina celastri (Spreng). Krong. \& Swincs as an indicator of atmospheric pollution in the province of Córdoba, Argentina, considering both lichen physiological parameters and element concentrations. Journal of Radioanalytical Chemistry, v.259, n.1, p.93-97, 2004.

NOWAK, D. J.; DWYER, J. F.; CHILDS, G. Los beneficios $y$ costos del enverdecimiento urbano. Áreas Verdes Urbanas en Latinoamérica México, Editorial Universidad Autónoma de Chapingo, 1997. p.17-38.

PANICHEV, N.; MC CRINDLE, R. The application of bioindicators for the assessment of air pollution. Journal of

Environmental Monitoring, v.6, n.1, p.121-123, 2004.

PERELMAN, P. et al. Análisis multielemental de cortezas de Fresno (Fraxinus_pennsylvanica) a lo largo de un gradiente urbano-periurbano en la metrópolis de Buenos Aires. Revista del Museo Argentino Ciencias Naturales, v. 8, n.2, p.231-236, 2006.

PIGNATA, M. L. et al. Atmospheric quality and distribution of heavy metals in Argentina employing Tillandsia capillaris as a biomonitors. Environmental Pollution, v.120, n.1, p.59-68, 2002.

PLA, R.; MORENO, M.; ADLER, M. The use of biomonitors and neutron activation analysis in the study of air pollution of Buenos Aires city. In: INTERNATIONAL WORKSHOP BIOMAP, Lisboa, 1997. Proceedings... Lisboa, International Atomic Energy Agency, 2000.

PULIAFITO, S. E. et al. La calidad del aire en Mendoza. Martínez Carretero, E.y Dalmasso, Antonio D. (eds). Mendoza Ambiental, 1995.

RUSU, A. M. et al. Biomonitoring using the lichen Hypogymnia physodes and bark samples near Zlatna, Romania immediately following closure of copper ore-processing plant.

Environmental Pollution, v.143, n.1, p.81-88, 2006. 
SPANGENBERG, A.; HOFMANN, F.;

KIRCHNER, M. Determining the agricultural ammonia immission using bark biomonitoring: comparison with passive sampler

measurements. Journal of

Environmental Monitoring, v.4, n.6, p.865-869, 2002.

WANNAZ, E. D. et al. Assessment of heavy metal accumulation in two species of Tillandsia in relation to atmospheric emission sources in Argentina. Science of the Total

Environment, v.361, p.267-279, 2006.

WONG, C. S. C.; XIANGDONG, L; THORNTON, I. Urban environmental geochemistry of trace metals. Environmental Pollution, v.142, n.1, p.1-16, 2006.
WALKENHORST,A.; HAGEMEYER, J.; BRECKLE,W. Passive monitoring of airborne pollutants, particularly trace metals with tree bark. In: MARKET, B. (Ed.) Plants as biomonitors. Indicators for heavy metals in the terrestrial environment Basel: VCH.Weinheim, 1993. p.523-540.

YAGHI, B.; ABDUL-WAHAB, S. A. Assessment of lead, zinc, copper, nickel and chromium in total suspended particulate matter from the workplace in Al-Rusayl Industrial Estate, Oman. Journal of Environmental Monitoring, v.5, n.6, p.950-952, 2003.

ZELLNER, M.; CAPURRO, A.; JANKILEVICH, S. Identificación de áreas de riesgo de contaminación atmosférica en la Ciudad de Buenos Aires.

Desarrollo Ambiental, n.10, paginas, 1996. 